\title{
FAKTA CERITA DALAM CERITA RAKYAT TOLAKI RANDA WULA'A
}

\author{
OLEH \\ Selti Juliana ${ }^{1}$, Sri Suryana Dinar ${ }^{2}$ dan Marwati ${ }^{3}$ \\ ${ }^{1}$ Alumni Jurusan Pend. Bahasa dan Sastra Indonesia, ${ }^{2,3}$ Dosen Jurusan \\ Pendidikan Bahasa dan Sastra Indonesia, Fakultas Keguruan dan Ilmu \\ Pendidikan Universitas Halu Oleo
}

\begin{abstract}
ABSTRAK
Penelitian ini bertujuan untuk mendeksripsikan dan menganalisis unsurunsur fakta cerita rakyat Tolaki Randa Wula'a. Penelitian ini adalah penelitian kepustakaan, dengan menggunakan metode deskriftif kualitatif. Data yang digunakan dalam penelitian ini adalah data tertulis berupa teks yang berhubungan dengan fakta cerita yang terkandung dalam cerita rakyat Tolaki Randa Wula'a. Sumber data dalam penelitian ini adalah cerita rakyat yang dimuat dalam buku Prosa dalam Sastra Tolaki yang diterbitkan oleh Departemen Pendidikan dan Kebudayaan Jakarta 1998. Tenik pengumpulan data teknik baca dan catat. Teknik analisis data menggunakan pendekatan struktural.Hasil penelitian menunjukan bahwa fakta cerita dalam Cerita Rakyat Tolaki RandaWula'a berupa adanya tokoh, tokoh utama dan tokoh tambahan. Tokoh utama diperankan oleh Putra Bungsu/Randa Wulaa dan tokoh tambahan diperankan oleh Lalewuta, Baginda Raja Lasiwuta, Anawai, keenam saudara Randa Wula'a, janda tua, dan Raja Lipuwuta(ayah Anawai). Pada data berikut ditemukan adanya alur yang melatar belakanggi terbentuknya fakta cerita dalam cerita rakyat Tolaki Randa Wula'a ini merupakan alur maju. Adapun unsur latarnya yaitu latar tempat yakni ialah rumah, sungai, hutan, gubuk. Latar waktu yang ditemukan yaitu pagi hari, tepat tengah malam, pada tengah malam, hari berganti hari, minggu berganti minggu, tepat tujuh jumat, dan genap tujuh hari. Sedangkan latar sosialnya yaitu keyakinan tokoh utama untuk mendapatkan apa yang ia inginkan.
\end{abstract}

Kata kunci: fakta cerita, cerita rakyat 


\section{PENDAHULUAN}

\subsection{Latar Belakang}

Indonesia

memiliki

keanekaragaman suku bangsa juga memiliki keanekaragaman bahasa daerah, dan dalam setiap bahasa daerah terdapat sastra daerah yang diciptakan oleh masyarakat pendukungnya. Sastra daerah di Indonesia sangat luas dan beragam. Setiap kelompok etnis, suku bangsa, masing-masing memiliki sastra daerah. Sastra daerah merupakan bagian dari suatu kebudayaan yang tumbuh dan berkembang ditengahtengah masyarakat. Salah satu upaya pengembangan budaya daerah saat ini ialah dengan mengekpresikan cerita rakyat sebagai budaya daerah dalam masyarakat itu sendiri.

Istilah sastra daerah tidak asing bagi orang Indonesia. Apapun makna dan referensi yang di berikan kepada kata itu, secara umum ada makna yang kira-kira sama, misalnya kegiatan lisan yang bukan percakapan sehari-hari, seperti cerita rakyat, puisi rakyat, cerita lisan yang hidup ditengah masyarakat, mantra dan juga pertunjukkan sastra daerah. Sastra daerah hidup pada masyarakat pertamanya, yaitu pada masyarakat yang melahirkan dan menghidupkanya. Keunikan sastra daerah yang dianggap dapat memperkaya khazanah kesusastraan nasional tampaknya telah menjadi perhatian penuh bagi para peneliti sastra.

Sastra lisan masyarakat Tolaki, dalam hal ini Cerita rakyat dapat kita temukan di masyarakat pendukungnya yang benar-benar mengetahuinya, dalam masyarakat Tolaki terdapat banyak cerita rakyat yang dapat kita temukan diantaranya kisah Oheo, kisah Onggabo, kisah kali Konawe'eha, kisah Randa Wula'a, kisah Elang Raksasa, kisah Haluoleo serta masih banyak cerita rakyat yang dapat kita temukan, yang kesemuanya masing-masing memiliki nilai-nilai tertentu yang dapat dimanfaatkan dalam kehidupan masyarakat Tolaki.

Cerita rakyat Tolaki tumbuh dan berkembang dalam berbagai jenis, bentuk, dan fungsinya secara turun temurun dari satu generasi ke generasi. Cerita rakyat Tolaki termasuk sastra daerah yang masih ada dan tersebar di tengah-tengah masyarakat Tolaki. Kenyataan diatas merupakan suatu gambaran bahwa karya sastra Tolaki itu masih perlu dikaji terus dan ditingkatkan, terutama pada cerita rakyat. Mengingat kapasitas cerita rakyat di tenggah masyarakat merupakan sesuatu hal yang masih menjadi perhatian oleh sebagian kelompok masyarakat.

Cerita rakyat memiliki pengembangan atau kadar suatu cerita yang cukup luas sehingga kita dapat menemukan berbagai unsur cerita di dalamnya yang memiliki unsur-unsur pembangun cerita. Umumnya orang-orang hanya mengetahui unsur-unsur karya fiksi pada unsur intrinsik dan unsur ekstrinsik sehingga sering kali mengabaikan unsur-unsur pembangun lainnya. Karya fiksi ialah suatu rekaan cerita yang disengaja ditulis oleh seorang pengarang. Hasil dari sebuah karya fiksi dapat membuat seseorang pembaca merasakan sesuatu yang terjadi dalam sebuah cerita. Hal itu 
dikarenakan adanya unsur-unsur pembangun sebuah cerita yang lain, bukan hanya unsur intrinsik ataupun ekstrinsik. Namun, di dalam unsur cerita fiksi terdapat berbagai unsurunsur yang lain, antara lain adalah fakta cerita, tema, dan sarana pengucapan.

Penelitian ini akan memfokuskan pokok permasalahan pada unsur fakta cerita. Unsur fakta dalam cerita meliputi karakter, alur dan latar. Struktur alur, karakter dan latar dalam sebuah cerita fiksi sangatlah berkaitan erat dan memiliki peranan penting dalam setiap cerita yang ditulis oleh penulis. Adanya karakter atau tokoh yang bergerak dalam cerita dan di dukung dengan keterkaitan latar cerita, alur yang disajikan akan berkembang dan akan semakin menambah ketertarikan pembaca dalam menghayati sebuah cerita. Buku Prosa dalam Sastra Tolaki merupakan karya sastra indonesia lama yang berbahasa Tolaki. Buku prosa dalam sastra Tolaki terdiri dari 17 cerita yang digolongkan atas beberapa jenis yaitu cerita yang termasuk mite, legenda, fable, dan cerita yang termasuk saga. Dari beberapa cerita tersebut penelitian ini difokuskan pada jenis saga, yakni cerita yang mengumgkapkan keberanian dan kepahlawanan seseorang. Termasuk pula dalam golongan ini ialah cerita tentang seorang pelaku yang mendapat kesaktian, lalu dengan kesaktianya itu ia dapat melakukan sesuatu yang luar biasa dalam mengatasi tantangan yang dihadapinya hal semacam ini terdapat dalam cerita Randa Wula'a. Alasan peneneliti memilih cerita rakyat Randa Wula'a karena dalam cerita Randa Wula'a selain menyajikan kearifan, juga mengisahkan kegigihan dan kesabaran. Karakter tokoh yang digambarkan merupakan karakterkarakter yang patut dianut. Dari karakter yang ditampilkan dalam cerita rakyat Tolaki Randa Wula'a inilah yang nantinya dapat mendidik dan mengarahkan pembaca untuk memiliki kedewasaan berfikir maupun bertingka laku. Penahapan alur yang unik serta unsur latar yang khas dari sebuah cerita rakyat. Selain itu, peneliti sudah pernah mendengar cerita tersebut di lingkungan keluarga, sehingga hal ini dapat memudahkan peneliti mengemukakan fakta cerita yang meliputi karakter, alur dan latar dalam cerita tersebut. Alasan lain pengambilan cerita rakyat ini dijadikan objek penelitian dikarenakan cerita tersebut masih kurang dikenal oleh masyarakat, sehingga ada kekhawatiran cerita rakyat ini akan hilang dan tidak dikenal lagi oleh generasi berikutnya. Selain itu penelitian ini diharapkan dapat mendorong minat baca, mengembangkan sastra daerah dan dapat melestarikannya.

Berdasarkan latar belakang inilah penulis tertarik menggunakan cerita rakyat Tolaki Randa Wula'a sebagai objek penelitian untuk mengungkap fakta cerita dalam cerita rakyat tersebut. Unsur-unsur yang terdapat pada fakta cerita seperti karakter, alur, dan latar. Mengingat bahwa cerita yang ada dalam cerita rakyat Tolaki Randa Wulaa tidak sepenuhnya sama persis dengan kenyataan yang ada dilingkungan kita. Untuk itu perlu dilakukan penelitian, agar lebih 
memahami fakta cerita dalam cerita rakyat ini.

\subsection{Rumusan Masalah}

Bagaimanakah fakta cerita yang terdapat pada cerita rakyat Tolaki Randa Wula'a?

\subsection{Tujuan Penelitian}

Adapun tujuan penelitian ini adalah untuk mendeksripsikan dan menganalisis unsur-unsur fakta cerita (Karakter tokoh, alur, latar) dalam cerita rakyat Tolaki Randa Wula'a.

\subsection{Manfaat Penelitian}

Berdasarkan latar belakang, rumusan masalah, dan tujuan, maka menjadi Maanfaat dalam penelitian ini adalah:

1. Sebagai sumber bacaan yang ingin memperdalam pengetahuan tentang khasanah sastra daerah Tolaki, khususnya cerita rakyat Tolaki.

2. Memperluas pengetahuan penikmat sastra terhadap fakta cerita dalam sebuah karya sastra.

3. Sebagai sumbangan pemikiran terhadap bahan ajar sastra yang berkenan dengan fakta cerita dalam karya sastra, atau cerita rakyat.

\subsection{BatasanOperasional}

Untuk menghindari kesalahan penafsiran tentang istilah yang digunakan dalam penelitian ini, maka dapat diuraikan beberapa istilah sebagai berikut.

1. Cerita rakyat adalah cerita lisan yang merupakan hasil tuturan langsung secara turun-temurun dari suatu generasi ke generasi.

2. Fakta cerita adalah unsur fiksi yang secara faktual dapat dibayangkan peristiwanya, eksistensinya dalam sebuah karya sastra.

3. Pendekatan struktural adalah pendekatan kesusatraan yang menekankan kajian hubungan antara unsur-unsur pembangun karya sastra yang bersangkutan.

\section{KAJIAN PUSTAKA}

\subsection{Pengertian Cerita Rakyat}

Cerita rakyat adalah golongan cerita yang hidup dan berkembang secara turun temurun dari satu generasi ke generasi berikutnya. Disebut cerita rakyat karena cerita ini hidup di kalangan rakyat dan hampir semua lapisan masyarakat mengenal cerita itu. Cerita rakyat milik masyarakat bukan milik seseorang.

Menurut Esten (1993: 5) cerita rakyat adalah suatu cerita yang pada dasarnya disampaikan oleh seseorang pada orang lain melalui penuturan lisan. Tokoh-tokoh dan peristiwa-peristiwa dalam cerita dianggap pernah terjadi pada masa lalu atau merupakan hasil rekaan semata karena terdorong oleh rasa keinginan menyampaikan pesan atau amanat melalui cerita itu.

\subsection{Ciri-ciri Cerita Rakyat}

Berdasarkan pengertian cerita rakyat yang sudah dibahas sebelumnya, maka ciri ciri cerita rakyat antara lain sebagai berikut.

1. Isi cipta sastranya bersifat pantastis, istana sentries, dan didaktis. Isi yang fantastis menggambarkan bahwa masyarakat pada waktu itu sangat diwarnai oleh kepercayaan animisme dan dinamisme. Isi yang istana sentries, maksudnya 
ceritanya berkisar pada pengisahan istana tentang keluarga raja yang sangat baik. Adapun sifat didaktisnya tampil karena cerita-ceritanya berusaha menggurui dan menamakan nilainilai pendidikan pada penikmatnya.

2. Bahasanya banyak menggunakan bahasa klise sebagai variasinya. Sering pula setiap cerita diawali dengan kata-kata, konon khabanya, sahibul hikayat.

3. Nama-nama pengarangnya sering tidak disebutkan, sehingga hasil sastranya kebanyakan anonim. Hal ini terjadi karena masyarakat lama cenderung bersifat kolektif, tidak mau muncul secara individual. Apabila ia berani tampil secara individual akan dinilai sebagai orang yang tak tahu adat. Badudu (dalam Rahmawati, 2006: 17-18).

\subsection{Jenis Cerita Rakyat Tolaki}

Berdasarkan peristiwa yang

diungkapkan serta pelaku yang

berperan dalam cerita. Sastra lisan

Tolaki dapat digolongkan atas

beberapa jenis yaitu. Sebagai berikut.

1. Cerita yang termasuk mite, yaitu cerita yang berbuhungan dengan alam gaib dan dewa-dewa yang kadang-kadang sulit terjangkau oleh akal. Hal semacam ini terdapat dalam cerita (1) Popiliano Oleo Ana Wula, (2) Sanggoleo Mbae,

Tarambu'no Anola Ranoa, (4) Pasa'eno, (5) Oheo

2. cerita yang termasuk legenda, yaitu cerita tentang kejadian alam yang menceritakan tentang asal mula sesuatu tempat atau bendabenda alam. Hal semacam ini terdapat dalam cerita. Konawe Eha ano Lasolo, Rongga Owase, Anggo Wose, Uti Owose, Moluwu, Onggabo.

3. cerita yang termaksud fable, yakni cerita tentang dunia binatang. Dalam cerita ini binatang dilukiskan sebagai manusia, pandai berkata-kata, berbuat, dan berpikir seperti manusia. Hal semacam ini terdapat dalam cerita $O$ wonggi rongga o Dongga, $O$ Dongga ronga Kolopua, Sima-sima $O$ 'Osao.

4. cerita termasuk saga, yakni cerita yang mengungkapkan keberanian dan kepahlawanan seseorang. Termasuk pula dalam golongan ini ialah cerita tentang seorang pelaku yang mendapat kesaktian, lalu dengan kesaktiannya itu ia dapat melakukan sesuatu yang luar biasa dalam mengatasi tantangan yang dihadapinya. hal semacam ini terdapat dalam cerita dalo-dalo minasabhu atau Randa Wulaa. Putri Annawula Ano Anadalo Matahara, La Bionda, To Tombaranowuta, HaluOleo, Langgai Saranani, Ana Masari Ala, Langgai Moriana, (Rahmawati, 2006:17).

\subsection{Fungsi Cerita Rakyat}

Bascom (dalam Rahmawati, 2006: 20) mengemukakan bahwa ada empat fungsi cerita rakyat lisan, yaitu sebagai berikut.

1. Cerita rakyat dapat mencerminkan angan-angan kelompok. Peristiwa yang diungkapkan dalam cerita ini sulit terjadi dalam kenyataan hidup sehari-hari. Jadi, cerita ini hanyalah merupakan proyeksi angan-angan atau impian rakyat 
jelata terutama gadis-gadis dan perjaka yang miskin.

2. Cerita rakyat berfungsi sebagai alat pendidikan budi pekerti kepada anak-anak atau tuntunan dalam hidup ini.

3. Cerita rakyat berfungsi sebagai alat pengendalian sosial (social control) atau sebagai alat pengawas agar norma-norma masyarakat dapat dipatuhi.

\subsection{Unsur-Unsur Cerita Rakyat}

Setiap karya fiksi memiliki unsur-unsur pembangun atau unsur sastra begitu pula dengan cerita rakyat. Cerita rakyat merupakan bagian sastra yang tidak bisa dipisahkan dari unsur-unsurnya baik unsur intrinsik maupun ekstrinsik.

Unsur intrinsik adalah unsurunsur cerita fiksi yang secara langsung berada di dalam, menjadi bagian, dan ikut membentuk eksistensi cerita yang bersangkutan. Unsur fiksi yang termasuk adalah tema, tokoh dan penokohan, alur dan berbagai peristiwa yang membentuknya, latar, sudut pandang, dan amanat. Sedangkan unsur ekstrinsik adalah unsur-unsur yang berada diluar karya sastra itu, secara tidak langsung mempengaruhi bangunan atau sistem organisme karya sastra. Atau secara lebih khusus ia dapat dikatakan sebagai unsur-unsur yang mempengaruhi bangun sebuah cerita karya sastra, namun sendiri tidak ikut menjadi bagian didalamnya. Walaupun demikian, unsur ekstrinsik cukup berpengaruh (untuk tidak dikatakan cukup menentukan) terhadap totalitas bangun cerita yang dihasilkan. Pembagian unsur intrinsik struktur karya sastra yang tergolong tradisional, adalah pembagian berdasarkan unsur bentuk dan isi (Nurgiyantoro, 2005: 221).

\subsection{Fakta Cerita}

Menurut

Stanton

(Nurgiyantoro, 2010:30-31) Fakta dalam cerita meliputi karakter (tokoh cerita), alur dan latar. Dalam sebuah teks fiksi sering dijumpai peristiwaperistiwa dan permasalahan yang diceritakan, karena kelihaian dan kemampuan imajinasi pengarang, tanpa konkret dan seperti-seperti benar ada dan terjadi. Apalagi jika ia ditopang oleh detil latar dan parah tokoh cerita yang meyakinkan, misalnya sengaja dikaitkan dengan kebenaran yang terjadi di dunia nyata, cerita itupun semakin meyakinkan pembaca. Pembaca seolah-olah menemukan sesuatu seperti yang ditemuinya dalam dunia realitas, maka peristiwa-peristiwa atau berbagai hal yang dikisahkan dalam cerita itu tidak lagi dirasakan sebagai sebagai cerita, sebagai manifestasi peristiwa imajinatif belaka, melainkan di anggap sebagai sesuatu yang bersifat faktual yang memang ada dan terjadi di dunia nyata.

\subsubsection{Karakter Tokoh}

Dalam pengkajian karya sastra, karakter tokoh dapat ditampilkan dalam berbagai ragam kararkter. Karakter yang ditampilkan telah difokuskan oleh pengarang kedalam diri tokoh-tokoh tersebut yang memiliki tipe-tipe manusia yang dikehendaki tema dan amanat perkembanganya haruslah wajar, dan dapat diterimah berdasarkan hubungan kualitas. Biasanya dalam cerita terdapat pelaku utama, 
sehinggah terdapat pelaku utama. Tokoh-tokoh lain ditampilkan dalam hubungan pelaku utama ini, sehingga terdapatlah pelaku tambahan. Cara paling tepat mengambarkan perwatakan seorang tokoh ialah dengan memberikan nama atau penamaan. Setiap penamaan adalah semacam kehidupan, menjiwai, dan mengidentifikasi.

Masalah tokoh dan karakter tokoh merupakan suatu hal yang kehadiranya dalam cerita fiksi sangat penting bahkan menentukan, karena tidak mungkin ada suatu karya fiksi tanpa ada tokoh yang bergerak dan pada akhirnya membentuk alur cerita. Tokoh digambarkan dengan ciri-ciri lahir, sifat dan sikap batinya agar wataknya dikenal pembaca. Tokoh-tokoh itu muncul dengan watak dengan karakter yang berbeda-beda sesuai dengan perhatian pengarang.

\subsubsection{Alur}

Menurut Stanton (2012:26) Alur merupakan rangkaian peristiwaperistiwa dalam sebuah cerita. Istilah alur biasanya terbatas pada peristiwa peristiwa yang terhubung secara kausal saja. Peristiwa kausal merupakan peristiwa yang menyebabkan atau menjadi dampak dari berbagai peristiwa lain dan tidak dapat diabaikan karena akan berpengaruh pada keseluruhan karya.

Alur dalam sebuah cerita harus bersifat padu antar peristiwa yang satu dengan yang lain, antara peristiwa cerita yang lebih dahulu dengan yang kemudian, ada hubungan, ada keterkaitan. Kaitan antar peristiwa tersebut harus jelas dan dapat dikenali hubungan waktu, dan alur sebuah cerita harus memiliki sifat keutuhan dan kepaduan.

\subsubsection{Latar}

Menurut Nurgiyantoro (2010: 216-217) mengemukakan bahwa latar atau setting yang disebut juga sebagai landas tumpu, menyaran pada pengertian tempat, hubungan waktu, dan lingkungan sosial tempat terjadinya peristiwa-peristiwa yang diceritakan. Latar memberikan pijakan cerita secara konkret dan jelas. Hal ini penting untuk memberikan kesan realitas kepada pembaca, menciptakan suasana tertentu yang seolah-olah sungguhsungguh ada dan terjadi.

Latar adalah tempat terjadinya peristiwa dalam suatu cerita, latar belakang fisik, serta unsur tempat dan waktu dalam suatu cerita. Latar menjukkan kepada pembaca kapan dan dimana peristiwa itu terjadi serta mempunyai hubungan dengan eksposisi (Yulisma, 1997: 5).

\subsubsection{Unsur Latar}

unsur latar dapat dibedakan kedalam tiga unsur pokok yaitu tempat, waktu, dan sosial. ketiga unsur itu walau masing-masing menawarkan permasalahan yang berbeda dan dapat dibicarakan secara sendiri, pada kenyataanya saling berkaitan dan saling mempengaruhi satu dengan yang lainnya (Nurgiyantoro, 2010: 227).

\subsection{Tema}

Selain fakta cerita (alur, tokoh, dan latar) unsur-unsur penting lainya lainnya dalam sebuah cerita rakyat adalah tema. Mempertanyakan makna sebuah 
karya, sebenarnya, juga berarti mempertanyakan tema. Setiap karya fiksi tentulah mengandung atau menawarkan tema, namun apa isi tema itu sendiri tak mudah ditunjukkan. Ia haruslah dipahami dan ditafsirkan melalui cerita dan data-data (baca: unsur-unsur pembangun cerita) yang lain.

Menurut Nurgiyantoro (2010: 25) mengemukakan bahwa tema adalah sesuatu yang menjadi dasar cerita. Ia selalu berkaitan dengan berbagai pengalaman kehidupan, seperti masalah cinta, kasih, rindu, takut, maut, religius, dan sebagainya. Dalam hal tertentu, sering, tema dapat disinonimkan dengan idea tau tujuan utama cerita.

\subsection{Pendekatan Struktural}

Salah satu cara untuk memahami karya sastra ialah dengan pendekatan struktural. Struktural adalah cara berfikir tentang dunia, terutama dalam kaitannya dengan resepsi dan deskrpsi struktur

Teeuw (dalam Apituley, 1991: 4-5) teori strukturalisme digunakan untuk menganalisis cerita sehingga dapat digambarkan unsur, tema, amanat, latar, penokohan,dan alur. Teori strukturalisme didasarkan pada pendapat bahwa karya sastra sebagai satu kesatuan yang bulat yang unsur-unsurnya mempunyai koherensi. Setiap unsur mendapat makna sepenuhnya dari hubungan keseluruhan unsur-unsur tersebut. Analisis struktur hendaknya diletakkan pada hubungan antara unsur-unsur sehingga totalitas lebih penting dari pada bagian-bagian.

\section{METODE DAN TEKNIK PENELITIAN}

3.1 Jenis Penelitian dan Metode Penelitian

\subsubsection{Jenis Penelitian}

Jenis penelitian yang digunakan dalam penelitian ini adalah penelitian kepustakaan. Dikatakan kepustakaan karena peneliti dalam mengumpulkan data sesuai dengan masalah yang dikaji dalam penelitian ini dilakuakan dengan cara mengkaji sumber tertulis yang berupa teks cerita rakyat Tolaki.

\subsubsection{Metode Penelitian}

Metode yang digunakan dalam penelitian ini adalah metode deskriptif kualitatif. Deskriptif yaitu penggambaran atau penyajian data berdasarkan kenyataan-kenyataan secara objektif sesuai dengan data yang terdapat dalam cerita rakyat Tolaki Randa Wula'a.

\subsection{Data dan Sumber Data}

\subsubsection{Data}

Data yang digunakan dalam penelitian ini adalah data tertulis, yaitu segala unsur fakta cerita dalam cerita rakyat Tolaki Randa Wula'a. Data tertulis berupa teks yang berhubungan dengan fakta cerita yang terkandung dalam cerita rakyat Tolaki Randa Wula'a.

\subsubsection{Sumber data}

Sumber data dalam penelitian ini adalah cerita rakyat yang dimuat dalam buku Prosa dalam Sastra Tolaki yang diterbitkan oleh Pusat Pembinaan dan Pengembangan Bahasa Departemen Pendidikan dan Kebudayaan Jakarta 1998. Cerita rakyat Tolaki yang dimuat dalam 
buku tersebut sebanyak 17 cerita. Peneliti menggambil sampel satu cerita yaitu cerita rakyat Randa Wula'a.

\subsection{Teknik Pengumpulan Data}

Tenik pengumpulan data yang digunakan dalam penelitian ini adalah teknik baca dan catat yang dilaksanakan sebagai berikut:

1. Teknik baca yakni suatu teknik yang dilakukan peneliti dengan membaca teks cerita rakyat yang menjadi objek dalam penelitian.

2. Teknik catat yakni mencatat datadata yang diperoleh dari hasil bacaan sesuai dengan masalah dalam penelitian.

\subsection{Teknik Analisis Data}

Pendekatan yang digunakan untuk mendeskripsikan fakta cerita dalam cerita rakyat Tolaki Randa Wula'a adalah pendekatan struktural. Pendekatan ini melihat karya sastra sebagai satu kesatuan yang utuh yang memiliki struktur yang saling berhubungan sehingga membentuk kebulatan makna. Langkah-langkah Menandai dan memberikan kode sesuai dengan kategori yang terdapat dalam fakta cerita yang dilakukan penulis untuk mengumpulkan dan menganalisis data adalah sebagai berikut.

1. Mengelompokkan data berdasarkan teori fakta cerita (Karakter tokoh, alur, dan latar) dalam cerita rakyat Tolaki Randa Wula'a.

2. Mendeskripsikan dan menganalisis fakta cerita (Karakter tokoh, alur, dan latar) dalam cerita rakyat Tolaki Randa Wula'a.
3. Menyimpulkan hasil analisis mengenai fakta cerita (Karakter tokoh, alur dan latar) yang terdapat dalam cerita rakyat Tolaki Randa Wula'a.

4. Membaca keseluruhan cerita rakyat Tolaki Randa Wula'a

\section{HASIL DAN PEMBAHASAN}

\subsection{Analisis Karakter Tokoh}

Dalam Cerita Rakyat Tolaki Randa Wula'a

Cerita rakyat Randa Wula'a di dalamnya terdiri atas beberapa tokoh yaitu Randa Wulaa, Anawai, Baginda Raja, keenam Saudara Randa Wulaa (Lalewuta, Lalewonua, Lelenggabo, Putri Sabe, Tina Nggapa, Putri Tinawana), Ahli Nujum, Janda Tua, Raja Lipuwuta, torotambi. Cerita rakyat tersebut menampilkan tokoh sentral atau tokoh utama dan tokoh bawahan atau tokoh tambahan. Tokoh utama dalam cerita rakyat tersebut adalah Randa Wulaa sedangkan yang lain adalah hanyalah berperan sebagai tokoh tambahan. Selanjutnya, keberadaan tokoh dalam suatu cerita dapat diketahui dengan beberapa ciri yang menggambarkan sifat dan karakternya.

\subsubsection{Tokoh Utama}

Tokoh utama dalam cerita rakyat ini adalah Randa Wula'a karena tokoh tersebutlah yang mendominasi cerita dari awal hingga akhir serta menjadi pusat permasalahan hingga selesai. Selain itu, Randa Wula'a merupakan tokoh yang paling terlibat dengan makna atau tema cerita. Randa Wula'a digambarkan sebagai putra bungsu dari enam orang bersaudara, ia mempunyai saudara laki-laki yang 
paling tertua yang bernama Lalewuta. Sosok Randa Wula'a adalah laki-laki yang sabar hal ini terlihat ketika keenam saudara kandung Randa Wula'a membuangnya ke sungai dan terdampar di hutan. Namun ia tidak melawan tetapi malah ia tetap sabar menerima perlakuan saudaranya Selain itu Randa Wula'a juga digambarkan sebagai sosok yang nekat, memiliki keteguhan hati, penolong. Hal itu tampak pada kutipan berikut ini

Ketika datang elang raksasa itu, Anawai telah mempersilakan diri untuk ditelan. Seketika itu pula Putra Bungsu menyuruh tali ajaibnya terbang mengikat kaki dan leher elang raksasa itu serta menyuruh golok ajaib menyembeli lehernya. Tiada berapa lama putuslah leher binatang raksasa itu dan terkaparlah ia dengan menghancurkan tujuh buah gunung dan tertimbunlah jurang yang dalam (hlm.25).

Dari kutipan di atas menggambarkan sosok Randa Wula'a yang penolong hal ini terlihat pada saat Putra Bungsu menggunakan kekuatan sakti untuk menolong Anawai putri raja pinggir laut yang akan ditelan oleh elang raksasa. Putra Bungsu menggunakan tali ajaib dan golok ajaibnya untuk menyembelih leher elang raksasa itu.

$$
\text { Randa Wula'a juga }
$$
mempunyai sifat pemaaf hal ini terlihat ketika Randa Wulaa memaafkan orang tua serta saudaranya.

\subsubsection{Tokoh Tambahan}

Tokoh tambahan dalam cerita rakyat Tolaki Randa Wula'a yaitu Lalewuta, Baginda Raja Lasiwuta, Ahli Nujum, Anawai, keenam saudara Randa Wula'a, janda tua, dan Raja Lipuwuta (ayah Anawai). Semua tokoh ini termasuk tokoh tambahan yang akan di bahas dalam penelitian ini. Tokoh tambahan merupakan tokoh yang berperan membantu/menemani tokoh utama dalam cerita, kehadirannya turut menonjolkan peranan dan perwatakan tokoh utama dan memperjelas tema pokok yang disampaikan. Selain itu, juga dapat membuat sebuah cerita menjadi realistis dan sesuai dengan kenyataan sehari-hari.

\section{Tokoh Lalewuta}

Tokoh Lalewuta digambarkan sebagai tokoh tambahan karena Lalewuta merupakan tokoh yang tidak banyak di ceritakan. Lalewuta merupakan kakak sulung Randa Wula'a yang bersifat jahat karena telah banyak menyusahkan Randa Wula'a.

2. Raja Lasiwuta (Ayah Randa Wula'a)

Raja Lasiwuta adalah seorang tokoh yang dalam cerita digambarkan sebagai orang tua Putra Bungsu dan keenam saudaranya. Sebagai orang tua Raja Lasiwuta bersikap tidak adil terhadap anak-anaknya.

3. Ahli Nujum

Ahli Nujum adalah orang yang pandai meramal nasib orang

4. Anawai

Anawai adalah seorang putri yang tahu membalas budi. 
Anawai juga seorang perempuan yang memiliki keteguhan hati

5 Keenam saudara Randa Wula'a (Lalewuta, Lalewonua, Lelenggabo, Putri Sabe, Tina Nggapa, Putri Tinawana).

Tokoh keenam saudara Randa Wula'a memiliki karakter yang jahat. Hal ini terlihat saat mereka mengetahui ramalan adiknya Putra Bungsu yang lebih baik dari mereka. Mereka langsung memukul adiknya dan membuangnya ke sungai.

5. Perempuan Tua

Perempuan tua sebagai penolong karena dialah yang memberi informasi kepada Putra Bungsu tentang gelang babi yang dapat membantunya nanti dalam melanjutkan perjalanan. Hal tersebut diberitahukanm lewat mimpi Putra Bungsu.

6. Janda Tua

Janda tua merupakan ibu asu

Randa Wula'a yang memiliki sifat kasih sayang terhadap Randa Wula'a dengan menganggapnya sebagai anak kandungnya sendiri dengan penuh kegembiraan dan keikhlasan ia merawat Randa Wula'a.

7. Raja Lipuwuta

Raja Lipuwuta adalah seorang tokoh yang dalam cerita digambarkan sebagai orang tua Anawai. Raja Lipuwuta memiliki sifat bijaksana karena ia berfikir dulu sebelum bertindak agar tidak akan merugikan diri sendiri ataupun orang lain. Sifat bijaksana berkaitan dengan kerendahan hati. Karena Raja Lipuwuta memiliki kerendahan hati maka akan memiliki sifat bijaksana dengan tidak terburu oleh nafsu sehingga berhati-hati dalam bertindak.

8. Torotambi

Torotambi merupakan pengawal raja yang bersifat penurut.

\subsection{Analisis Alur Dalam Cerita Rakyat Tolaki Randa Wulaa}

Alur dalam cerita ini adalah alur maju. Hal ini dikarenakan keseluruhan cerita disampaikan dengan terus ke depan menjawab setiap sebab yang ditimbulkan dari setiap konflik. alur cerita ini dapat kita lihat pula pada jalinan cerita yang dimulai dari perjalanan Putra Bungsu dan keenam saudaranya menemui ahli nujum untuk di ramal. Karena hasil ramalan itu hanya Putra Bungsu yang mendapatkan ramalan yang baik yaitu akan menghimpun ketujuh daerah kerajaaan dan sekaligus menjadi rajanya serta akan mempermaisurikan Putri Raja pinggi laut. Randa Wula'a sangat dibenci oleh saudara-saudaranya yang lain akibat hasil ramalan ahli nujum tentang nasib mereka bertujuh ke depan. Akibat kebencian itu ia diasingkan oleh saudaranya dengan cara dihanyutkanya ke sungai dengan menggunakan rakit. Randa Wula'a akhinya terdampar di sebuah pulau yang sangat angker. Di pulau tersebut, ia berhasil mengambil gelang milik babi raksasa, penjaga pulau tersebut, bahkan berhasil menenggelamkan babi tersebut di tenga laut. Selain gelang itu iapun mendapatkan beberapa benda sakti, yaitu tali dan golok. Ketika singgah di sebuah pulau untuk istirahat, ia bertemu dengan putri raja, bernama Anawai yang sedang pasrah menunggu nasibnya dimakan elang 
raksasa. Randa Wula'a berusaha menyelamatkan putri tersebut dengan membunuh elang itu. Pada akhir cerita, digambarkan bahwa Randa Wula'a berhasil mempersunting Anawai, kemudian diangkat menjadi raja.

Cerita ini mengisahkan keberhasilan seseorang yang bernama Randa Wula'a dalam menjalani liku-liku kehidupannya. banyak tantangan yang menghadang diatasinya satu-persatu dengan baik. Peristiwanya berawal ketika saudarasaudaranya memberikan laporan palsu tentang dirinya kepada raja, orang tuanya sendiri yang mengakibatkan Randa Wula'a harus diasingkan dari lingkungan keluarga dengan jalan dihanyutkan ke tengah laut. Ketegangan terus meningkat dengan munculnya babi raksasa untuk membinasakan siapa saja yang datang ke daerah kekuasaanya. Peristiwanya semakin menegangkan dengan munculnya burung elang raksasa yang tentu saja tidak hanya ingin menghabisi Anawai, tetapi juga menjadi ancaman serius bagi dirinya. Berkat kesaktian dan keberaniannya, Randa Wulaa dapat membunuh dua binatang tersebut. Peristiwa mulai menurun dengan keluarnya keputusan raja untuk mengawinkan Randa Wula'a dengan Anawai, bahkan menobatkannya sebagai raja.

\subsection{Analisis Latar}

latar atau setting menyaran pada pengertian tempat, hubungan waktu, dan lingkungan sosial tempat terjadinya peristiwa-peristiwa yang diceritakan. Latar memberikan pijakan cerita secara konkret dan jelas. Hal ini penting untuk memberikan kesan realitas kepada pembaca, menciptakan suasana tertentu yang seolah-olah sungguhsungguh ada dan terjadi

\subsubsection{Latar Tempat}

Adapun penggunaan latar tempat dalam cerita Rakyat ini dapat digambarkan dalam sejumlah tempat yang beberapa diantaranya ialah rumah, sungai, hutan, dan gubuk.

Penggunaan latar tempat rumah seperti pada kutipan berikut.

" Hai, Lelewuta! Besok pagi, kau ajak adikmu pergi ke rumah dukun, ahli nujum, supaya kalian dapat mengetahui rezeki dan penghidupan yang akan kalian temui dan jumpai diatas dunia"

Esok harinya, putra sulung Lalewuta mengajak adik-adiknya pergi ke rumah dukun, seorang ahli nujum. Tak berapa lama sampailah mereka di rumah dukun. Dengan terpogoh-pogoh, dukun menyambut kedatangan ketujuh orang anak raja itu, seraya bertanya, "Apakah keperluan yang mendadak sehingga sepagi buta ini kalian berbondong-bondong datang di gubuk saya ?" putra sulung Lalewuta menerangkan pesan baginda raja. Setelah sang dukun mendengarkan pesan baginda raja, mulailah ia melaksanakan tugasnya menujum. (hlm. 19).

Kutipan tersebut menggambarkan latar tempat yaitu rumah Ahli Nujum sebagai salah satu tempat tokoh diceritakan. Kutipan tersebut menjelaskan tempat Ahli Nujum meramal Randa Wula'a dan saudaranya. Deskripsi latar cerita rakyat tersebut mengambarkan 
bahwa cerita yang digambarkan itu benar-benar terjadi.

\subsubsection{Latar Waktu}

Latar waktu yang digunakan dalam cerita rakyat Randa Wula'a adalah tepat hari juma't, pagi hari, tepat tengah malam, pada tengah malam, hari berganti hari, minggu berganti minggu, tepat tujuh jumat, dan genap tujuh hari. Tiap kondisi tersebut dikaitkan dengan aktivitas para tokoh dalam cerita. Hal itu tampak pada kutipan berikut.

Persiapan pesta pernikahan telah baginda raja persiapkan. Waktu berjalan terus dan tibalah hari jumat, hari yang ditentukan oleh baginda raja (hlm. 30).

Kutipan di atas mengambarkan bahwa dalam persiapan pernikahan Randa Wula'a tepat hari Jumat hari yang di tentukan Baginda Raja. Randa Wula'a membersikan dirinya dengan mandi disungai. Randa wula'a terus melakukannya kemudian ia bercermin. Parasnya sudah bisa duduk di tempat peraduan, bahkan di singgasananya raja sekalipun.

"Hai, Lalewuta! Besok pagi, kau ajak adik-adikmu pergi ke rumah dukun, ahli nujum, supaya kalian dapat mengetahui rezeki dan penghidupan yang akan kalian temui dan jumpai di atas dunia" (hlm.19).

Kutipan tersebut menjelaskan bahwa pada paginya, Lalewuta putra tertua dari kerajaan harus mengajak adik-adiknya untuk pergi ke rumah dukun, ahli nujum. Supaya mengetahui rezeki dan penghidupan yang akan mereka temui dan jumpai diatas dunia.

\subsubsection{Latar Sosial}

Latar sosial berhubungan dengan kehidupan sosial masyarakat pada tempat yang diceritakan dalam karya. Tata cara kehidupan sosial masyarakat mencakup berbagai masalah dalam lingkup yang cukup kompleks. Ia dapat berupa kebiasaan hidup, adat istiadat, tradisi, keyakinan, pandangan hidup, cara berifikir, dan bersikap.

Kepercayaan adalah nilai yang berhubungan dengan keyakinan dan tingkat keimanan terhadap apa yang menjadi kekuasaan Allah Swt. kepercayaan merupakan anggapan atau keyakinan bahwa sesuatu yang di percayai itu benar atau nyata adapun kepercayaan yang dimaksud dalam cerita rakyat ini yaitu, kepercayaan terhadap dukun dan kepercayaan terhadap kekuatan sakti atau gaib. Kepercayaan pada dukun masih nampak dalam kehidupan masyarakat tetapi, hanya sebagian orang saja yaitu, orang-orang awam yang bertempat tinggal di daerahdaerah pelosok. Hal itu disebabkan karena ekonomi lemah dan tidak memiliki pendidikan sehingga kehidupan mereka lebih mengarahkan dengan mempercayai dukun sedangkan masyarakat yang memiliki pengetahuan dan pendidikan sudah tidak lagi percaya kepada dukun karena mereka sudah memiliki agama dan pendidikan.

Adanya kepercayaan kepada dukun atau ahli nujum ketika raja Lasiuta menyuruh anak-anaknya pergi bernujum ke rumah dukun. Hal tersebut dapat dilihat pada kutipan berikut.

Pada suatu ketika bartahtala seorang raja yang bernama raja Lasiuta. Sementara ia duduk di 
singgasananya, tiba-tiba ia memanggil anaknya yang tertua bernama Lalewuta. "hai Lalewuta! Besok pagi, kau ajak adik-adikmu pergi kerumah dukun, ahli nujum, supaya kalian dapat mengetahui rezeki dan penghidupan yang akan kalian temui dan jumpai di atas dunia (hlm. 19)

Kutipan di atas mengambarkan Raja Lasiuta memerintahkan kepada anak sulungnya yaitu Lalewuta untuk mengajak adik-adiknya ke rumah ahli nujum untuk meramalkan nasib mereka agar dapat mengetahui rezeki dan penghidupan di masa depan.

Penggunaan latar dalam cerita rakyat ini baik latar tempat, waktu, dan sosial bertujuan untuk memberi informasi dan Penjelasan kepada pembaca. Kehadiran latar ini dapat memberikan kesan dalam benak pembaca sehingga uraian peristiwa dapat tampak secara hidup bagi orang yang membacanya.

\subsection{Tema Cerita Rakyat Tolaki Randa Wula'a}

Tema adalah gagasan, ide, atau pilihan utama yang mendasari suatu karya sastra. Tema tidak bisa disamakan dengan pokok masalah atau topik. Tema dapat juga disebut sebagai gagasan yang mendasari karya sastra Sudjiman (dalam Rahmawati, 2006: 8). Dalam sastra lisan sering ditemukan tema yang bersifat didaktis, penyajianya biasanya dalam

\section{PENUTUP}

\subsection{Kesimpulan}

Berdasarkan penelitian yang dilakukan terhadap fakta cerita dalam cerita rakyat Tolaki Randa Wulaa dapat disimpulkan bahwa fakta cerita dalam Cerita Rakyat Tolaki Randa Wulaa adalah berupa adanya tokoh, tokoh utama dan tokoh tambahan. Tokoh utama diperankan oleh Putra Bungsu/Randa Wulaa dan tokoh tambahan diperankan oleh Lalewuta, Baginda Raja Lasiwuta, Anawai, keenam saudara Randa Wulaa, janda tua, dan Raja Lipuwuta(ayah Anawai). Pada data berikut ditemukan adanya alur yang melatar belakanggi terbentuknya fakta cerita dalam cerita rakyat Tolaki Randa Wulaa ini merupakan alur maju. Adapun unsur latarnya yaitu latar tempat yakni ialah rumah, sungai, hutan, gubuk. Latar waktu yang ditemukan yaitu tepat hari jumat, pagi hari, tepat tengah malam, pada tengah malam, hari berganti hari, minggu berganti minggu, tepat tujuh jumat, dan genap tujuh hari. Sedangkan latar sosialnya yaitu keyakinan tokoh utama untuk mendapatkan apa yang ia inginkan.

\subsection{Saran}

Dalam fakta-fakta cerita kita dapat menemukan banyak nilai yang dapat diterapkan dalam kehidupan sehari-hari. Hal ini juga mengingat pada kita bahwa cerita rakyat itu bukanlah sebuah hal yang kuno dan akan hilang bersama terus berkembangya zaman, melainkan cerita rakyat juga merupakan karya sastra yang kita kembangkan dan tetap menjaga kelestarianya. Karena dalam cerita rakyat banyak pelajaran yang dapat diambil. Sekiranya peneliti selanjutnya terhadap cerita rakyat Tolaki perlu dilakukan, mengingat banyaknya cerita rakyat dalam masyarakat Tolaki dan diduga banyak mengandung nilai-nilai kehidupan. 
DAFTAR PUSTAKA

Apituley, A Leo. 1991. Struktur Sastra Lisan Tontemboan. Jakarta: Departemen Pendidikan dan Kebudayaan.

Danandjaja, James. 1991. Folklor Indonesia Ilmu gosip, dongeng, dan lain-lain. Jakarta: PT Pustaka Utama Grafiti.

Endraswara, Suwardi. 2013. Metodologi Penelitian Sastra. Yogyakarta: CAPS(Center for Academic Publishing Service).

Esten, Mursal, dkk. 1993. Struktur Sastra Lisan Kerinci. Jakarta: Yayasan Obor Indonesia.

Mahmud, Saifuddin, dkk. 2000. Struktur Sastra Lisan

Simeulue. Jakarta: Pusat Bahasa.

Mulawati, 2008. Kandai: Majalah Ilmiah Bahasa dan Sastra. Kantor Bahasa Provinsi Sulawesi Tenggara.

Nasruddin dan Haruddin, 1998. Prosa dalam Sastra Tolaki. Jakarta: Pusat Pembinaan dan Pengembangan Bahasa Departemen Pendidikan dan Kebudayaan.

Nurgiyantoro, Burhan. 2005. Sastra Anak pengantar Pemahaman Dunia Anak. Yogyakarta: Gadjah Mada University Press.

Nurgiyantoro, Burhan. 2010. Teori Pengkajian Fiksi. Yogyakarta: Gadjah Mada University Press.

Nurgiyantoro, Burhan. 2013. Teori Pengkajian Fiksi. Yogyakarta: Gadjah Mada University Press.

Nurgiyantoro, Burhan. 2015. Teori pengkajian Fiksi. Yogyakarta: Gadjah Mada University Press.

Rahmawati, S.S. 2006. Analisis Aktansial dan Fungsional Cerita Saga Dalam Sastra Lisan Tolaki. Departemen
Pendidikan Nasional Pusat Bahasa: Kantor Bahasa Sulawesi Tenggara.

Ratna, Nyoman Kutha. 2008. Teori, Metode, dan Teknik Penelitian Sastra. Yogyakarta: Pustaka Pelajar.

Semi, M. Atar. 1993. Metode Penelitian Sastra. Bandung: Angkasa.

Santosa, Puji. 2015. Metode Penelitian Sastra. Yogyakarta: azzagrafika.

Stanton, Robert. 2012. Teori Fiksi. Yogyakarta: Pustaka Pelajar.

Sukada, Made. 1987. Beberapa Aspek Tentang Sastra. Denpasar: Kayumas \& Yayasan Ilmu dan Seni Lesiba.

Sugiyono. 2017. Metode Penelitian Kuantitatif, Kualitatif, dan $R \& D$. Bandung: Alfabeta.

Wicaksono, Andri. 2014. Pengkajian Prosa Fiksi. Yogyakarta: Garudhawaca.

Yulisma, 1997. Struktur Sastra Lisan Daerah Jambi. Jakarta: Pusat Pembinaan dan Pengembangan Bahasa. 